Keywords:

Musical instruments

Physical and mechanical properties

Tropical woods

Wood anatomy

Historic:

Recebido 22/09/201 I

Aceito 08/10/2013

Palavras chave: Instrumentos musicais Propriedades físicas e mecânicas

Madeiras tropicais Anatomia da madeira

Correspondence: edulongui@gmail.com
Eduardo Luiz Longui', Israel Luiz de Lima', Daniel Romeu Lombardi², José Nivaldo Garcia ${ }^{3}$, Edenise Segala Alves ${ }^{4}$

\section{WOODS WITH PHYSICAL, MECHANICAL AND ACOUSTIC PROPERTIES SIMILAR TO THOSE OF Caesalpinia echinata HAVE HIGH POTENTIAL AS ALTERNATIVE WOODS FOR BOW MAKERS}

ABSTRACT: For nearly two hundred years, Caesalpinia echinata wood has been the standard for modern bows. However, the threat of extinction and the enforcement of trade bans have required bow makers to seek alternative woods. The hypothesis tested was that woods with physical, mechanical and acoustic properties similar to those of $C$. echinata would have high potential as alternative woods for bows. Accordingly, were investigated Handroanthus spp., Mezilaurus itauba, Hymenaea spp., Dipteryx spp., Diplotropis spp. and Astronium lecointei. Handroanthus and Diplotropis have the greatest number of similarities with $C$. echinata, but only Handroanthus spp. showed significant results in actual bow manufacture, suggesting the importance of such key properties as specific gravity, speed of sound propagation and modulus of elasticity. In practice, Handroanthus and Dipteryx produced bows of quality similar to that of $C$. echinata.

\section{MADEIRAS COM PROPRIEDADES FíSICAS, MECÂNICAS E ACÚSTICAS SEMELHANTES ÀS DE Caesalpinia echinata POSSUEM POTENCIAL COMO MADEIRAS ALTERNATIVAS PARA ARQUETEIROS}

RESUMO: Por quase 200 anos, a madeira de Caesalpinia echinata tem sido referência para arcos modernos. No entanto, a ameaça de extinção e a proibição comercial têm motivado os arqueteiros a buscar madeiras alternativas. A hipótese testada foi a de que madeiras com propriedades físicas, mecânicas e acústicas semelhantes às de $C$. echinata, teriam grande potencial como madeiras alternativas para os arcos. Assim, foram investigadas Handroanthus spp., Mezilaurus itauba, Hymenaea spp., Dipteryx spp., Diplotropis spp. e Astronium lecointei. Os resultados mostraram que Handroanthus e Diplotropis apresentam - maior número de semelhanças com C. echinata, mas apenas Handroanthus teve resultados significativos na fabricação dos arcos, sugerindo a importância das seguintes propriedades chave: densidade aparente, velocidade de propagação do som e módulo de elasticidade. Na prática, Handroanthus e Dipteryx forneceram arcos com qualidade semelhante ao de $C$. echinata.
DOI: 10.1590/01047760201420031345
I Instituto Florestal do Estado de São Paulo - São Paulo, São Paulo, Brazil

${ }^{2}$ Arcos Lombardi - São Paulo, São Paulo, Brazil

${ }^{3}$ Escola Superior de Agricultura Luiz de Queiroz - Piracicaba, São Paulo, Brazil

${ }^{4}$ Instituto de Botânica - São Paulo, São Paulo, Brazil 


\section{INTRODUCTION}

Although hundreds of wood species are known in the world, luthiers have used only a small number of species for centuries. This stems from traditionalism, but also from the physical, mechanical and acoustic properties of those woods (SLOOTEN; SOUZA, 1993; SOUZA, 1983). Similarly, for stringed instruments, the wood of Caesalpinia echinata (pau-brasil or pernambuco) has been the standard for bows for nearly two hundred years (BAINES, I96I; BRÉMAUD et al., 2008; BUENO, 2002; HOLZ, 1996; MATSUNAGA et al., 1996; RYMER, 2004; WEGST et al., 2007).

Physical, mechanical and acoustic properties are considered in the selection of woods for musical instruments (BRÉMAUD et al., 2008). According to Schimleck et al. (2009) and Wegst (2006), density is particularly important for the selection of woods for musical instruments and bows. Alves et al. (2008b) and Longui et al. (2010a) showed that wood with high quality for bows presented a specific gravity higher than $950 \mathrm{~kg} \cdot \mathrm{m}^{-3}$. The elastic properties of wood also directly influence the quality of the sticks for bows (ALVES et al., 2008b; BRÉMAUD et al., 2008; MATSUNAGA et al., 1996; WEGST et al., 2007).

Knowledge of these and other properties of wood, as well as its behavior under compression and shear stresses, can lead to the selection of the most suitable woods for bows. In particular, the production of test bows represents the ideal situation for the selection of woods because it allows the chance to establish workability based on anatomic characteristics. It also establishes the wood properties which qualify the sticks for bows.

Since the wood of $C$. echinata has become scarce, it was hypothesized that woods with physical, mechanical and acoustic properties similar to those of $C$. echinata would have high potential as alternative woods for bows. Accordingly, it should be possible to identify woods for bows based on these properties. Therefore, in this paper, the physical, mechanical and acoustic properties of the following woods were compared with those of C. echinata, as the reference wood for modern bows: Handroanthus spp., Mezilaurus itauba, Hymenaea spp., Dipteryx spp., Diplotropis spp. and Astronium lecointei.

\section{MATERIAL AND METHODS}

\section{Wood species}

Five planks of Handroanthus spp. (ipê) Bignoniaceae and three planks each of Mezilaurus itauba (itaúba) - Lauraceae, Hymenaea spp. (jatobá) Fabaceae, Dipteryx spp. (cumaru) - Fabaceae, Diplotropis spp. (sucupira) - Fabaceae and Astronium lecointei (muiracatiara) - Anacardiaceae were purchased in the wood market in São Paulo. Samples with specific gravity above $950 \mathrm{~kg} \cdot \mathrm{m}^{-3}$ and no defects were selected. To ensure that the planks were from different trees, only one plank was randomly purchased in each woodwork supply store. To confirm their identification, the woods were analyzed with a 10x hand lens and later compared with samples from the Forestry Institute Xylarium (SPSFw). Besides the above six woods, were also studied samples of $C$. echinata donated by one of the authors.

\section{Sampling}

The analyses of the six studied woods were performed in three steps:

I) The wood planks were cut into sticks measuring $700 \mathrm{~mm} \times 15 \mathrm{~mm} \times 15 \mathrm{~mm}$ and denominated long sticks (Figure I). Eighteen long sticks were selected, three of each wood, and their specific gravity, speed of sound propagation and dynamic elasticity modulus were determined. Data from the six woods were then compared with those from the high quality sticks of $C$. echinata, as published by Alves et al. (2008b).

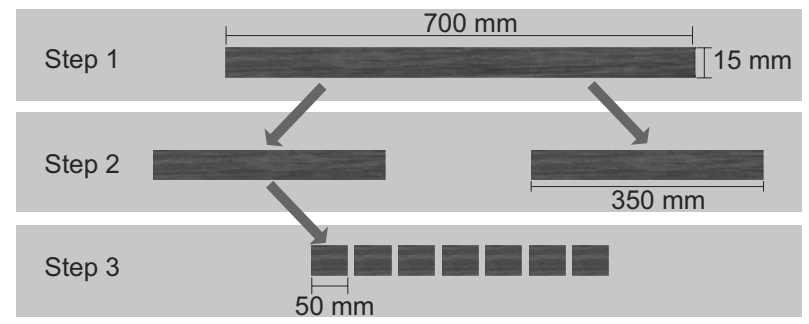

FIGURE I Schematic representation of the sampling at each step of the study.

FIGURA I Representação esquemática da amostragem em cada etapa do estudo.

2) Each long stick was crosscut in half to provide two short sticks (350 $\mathrm{mm}$ in length). In addition to six potential woods from this step, samples of $C$. echinata was also evaluated. Bending test was carried out in just one of the two short sticks and obtained the static modulus of elasticity and the modulus of rupture totaling three replications for each wood.

3) Each of the remaining 18 short sticks was cut into seven samples $50 \mathrm{~mm}$ in length. Shear parallel to the grain was calculated in three samples, and in the other three, the volumetric shrinkage was determined. 
Compression parallel to the grain was performed in one sample.

\section{Wood properties}

In the tests for specific gravity $\left(\rho_{\text {ap }}\right)$, static modulus of elasticity $\left(M O E_{s}\right)$, modulus of rupture (MOR), shear parallel to the grain $\left(f_{v 0}\right)$, volumetric shrinkage $\left(\varepsilon_{v}\right)$, and compression parallel to the grain $\left(\mathrm{fc}_{0}\right)$, the standard NBR-7 190/97 (ASSOCIAÇÃO BRASILEIRA DE NORMAS TÉCNICAS - ABNT, 1997) was employed, adjusting the dimensions of the samples. The tests were performed on a universal testing machine (Contenco UMC-300).

\section{Speed of sound propagation}

The speed of sound propagation was determined with a G. Lucchi Elasticity Tester. The equipment emits an ultrasonic pulse from a transducer placed in contact with one end of the sample, and the pulse is detected by a receiver placed at the other end. Sample length was determined with measuring tape. Then, the speed of sound propagation was calculated according to equation I (LUCCHI, I 986), where $v$ = speed of sound propagation $\left(\mathrm{m} \cdot \mathrm{s}^{-1}\right) ; \mathrm{m}=$ stick length in meters; and $\mathrm{s}=$ time for the ultrasonic pulse to pass through the stick in seconds.

$$
\mathrm{v}=\mathrm{m} \cdot \mathrm{s}^{-1}
$$

\section{Dynamic Modulus of Elasticity $\left(\mathrm{MOE}_{\mathrm{d}}\right)$}

This property was calculated with the values of specific gravity and speed of sound propagation, using the equation 2, where $\mathrm{MOE}_{\mathrm{d}}=$ dynamic modulus of elasticity $(\mathrm{MPa}), \mathrm{v}=\operatorname{velocity}\left(\mathrm{m} \cdot \mathrm{s}^{-1}\right)$, and $\rho_{\mathrm{ap}}=$ specific gravity $\left(\mathrm{kg} \cdot \mathrm{m}^{-3}\right)$.

$$
\mathrm{MOE}_{\mathrm{d}}=\left(\mathrm{v}^{2} / 100\right) \cdot \rho_{\mathrm{ap}}
$$

\section{Statistical analysis}

Kruskal-Wallis One Way Analysis of Variance on Ranks was performed to identify differences among the woods and Multiple Comparisons versus Control Group (Dunn's Method) to detect which wood had properties most similar to those of $C$. echinata (control group). Bylinear regression analysis was investigated whether variations of specific gravity and speed of sound propagation could be observed along the sticks of potential woods.

\section{RESULTS}

\section{Physical, acoustic and mechanical properties of the long sticks}

The specific gravity of Diplotropis spp. and Hymenaea spp. wood does not differ from that of C. echinata. Handroanthus spp. wood was similar to the control group with respect to the speed of sound propagation. Dipteryx spp. wood was in the same range of $\mathrm{MOE}_{d}$ as that shown by $C$. echinata (Figure 2). Concerning the long sticks, the specific gravity of Diplotropis spp. and Hymenaea spp, the speed of sound propagation of Handroanthus spp, and the $\mathrm{MOE}_{\mathrm{d}}$ of Dipteryx spp. did not significantly differ from the same properties in C. echinata (Figure 2).
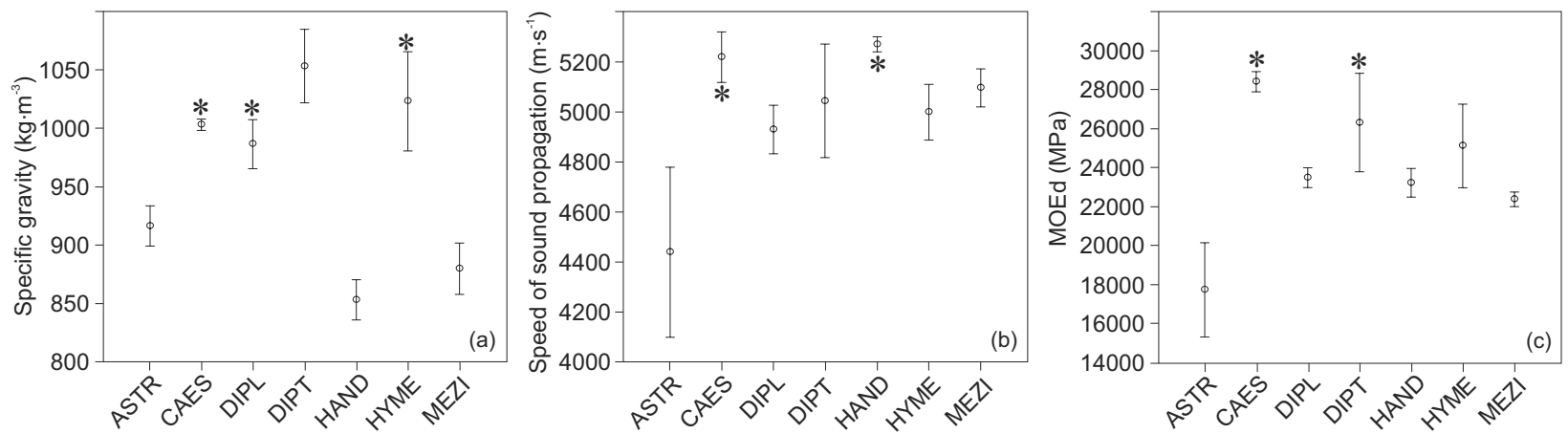

FIGURE 2 Variation in specific gravity (a), speed of sound propagation (b) and dynamic modulus of elasticity (MOE ${ }_{d}$ ) (c) in the long sticks $(700 \mathrm{~mm})$. Asterisks indicate that the woods are similar to $C$. echinata $(\mathrm{P}<0.00 \mathrm{I})$ by Multiple Comparisons versus Control Group (Dunn's Method). Astronium lecointei (ASTR), Caesalpinia echinata (CAES), Diplotropis spp. (DIPL), Dipteryx spp. (DIPT), Handroanthus spp. (HAND), Hymenaea spp. (HYME), Mezilaurus itauba (MEZI).

FIGURA 2 Variação na densidade aparente (a), velocidade de propagação do som (b) e módulo de elasticidade dinâmico $\mathrm{MOE}_{\mathrm{d}}$ (c) nas varetas longas $(700 \mathrm{~mm})$. Asteriscos indicam similaridades com $C$. echinata $(\mathrm{P}<0.00 \mathrm{I})$ pelo Multiple Comparisons versus Control Group (Dunn's Method). Astronium lecointei (ASTR), Caesalpinia echinata (CAES), Diplotropis spp. (DIPL), Dipteryx spp. (DIPT), Handroanthus spp. (HAND), Hymenaea spp. (HYME), Mezilaurus itauba (MEZI). 


\section{Mechanical properties of the short sticks}

In static bending tests using short sticks was observed that $\mathrm{MOE}_{\mathrm{s}}$ of Hymenaea spp. and MOR of Diplotropis spp. and Dipteryx spp. did not significantly differ from these properties of $C$. echinata (Figure 3).
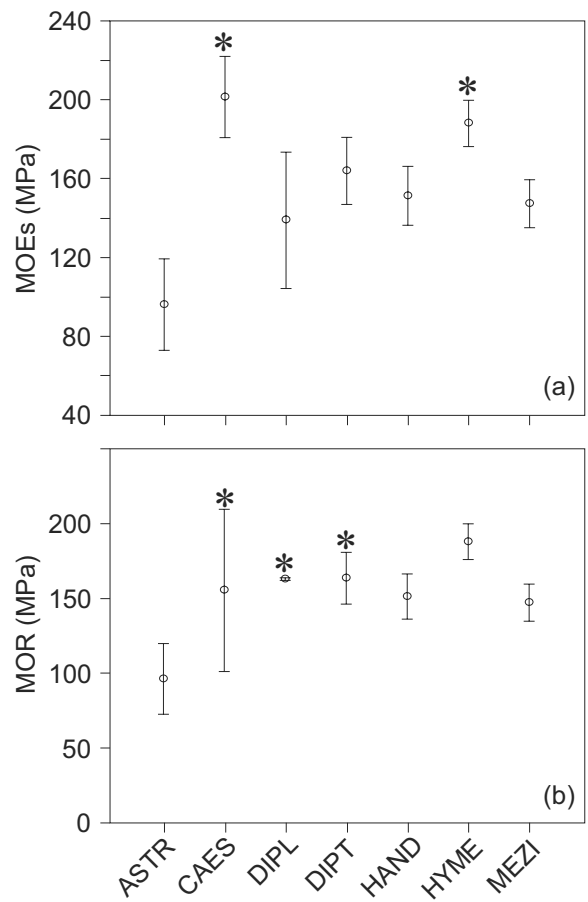

FIGURE 3 Variation in static modulus of elasticity $\left(\mathrm{MOE}_{\mathrm{s}}\right)$ (a) modulus of rupture (MOR) (b). Asterisks indicate that the woods are similar to $C$. echinata $(P<0.001)$ by Multiple Comparisons versus Control Group (Dunn's Method). Astronium lecointei (ASTR), Caesalpinia echinata (CAES), Diplotropis spp. (DIPL), Dipteryx spp. (DIPT), Handroanthus spp. (HAND), Hymenaea spp. (HYME), Mezilaurus itauba (MEZI).

FIGURA 3 Variação do módulo de elasticidade estático $\mathrm{MOE}_{\mathrm{s}}$ (a) módulo de ruptura MOR (b). Asteriscos indicam similaridades com $C$. echinata $(P<0.00$ I $)$ pelo Multiple Comparisons versus Control Group (Dunn's Method). Astronium lecointei (ASTR), Caesalpinia echinata (CAES), Diplotropis spp. (DIPL), Dipteryx spp. (DIPT), Handroanthus spp. (HAND), Hymenaea spp. (HYME), Mezilaurus itauba (MEZI).

\section{Variation in specific gravity and speed of sound propagation along the short sticks}

The variation of speed of sound propagation and specific gravity along the short sticks were also evaluated. Speed of sound propagation did not vary along the stick, while the specific gravity varied significantly in the sticks of Hymenaea spp., M. itauba, Diplotropis spp. and $A$. lecointei (Figure 4a-c).
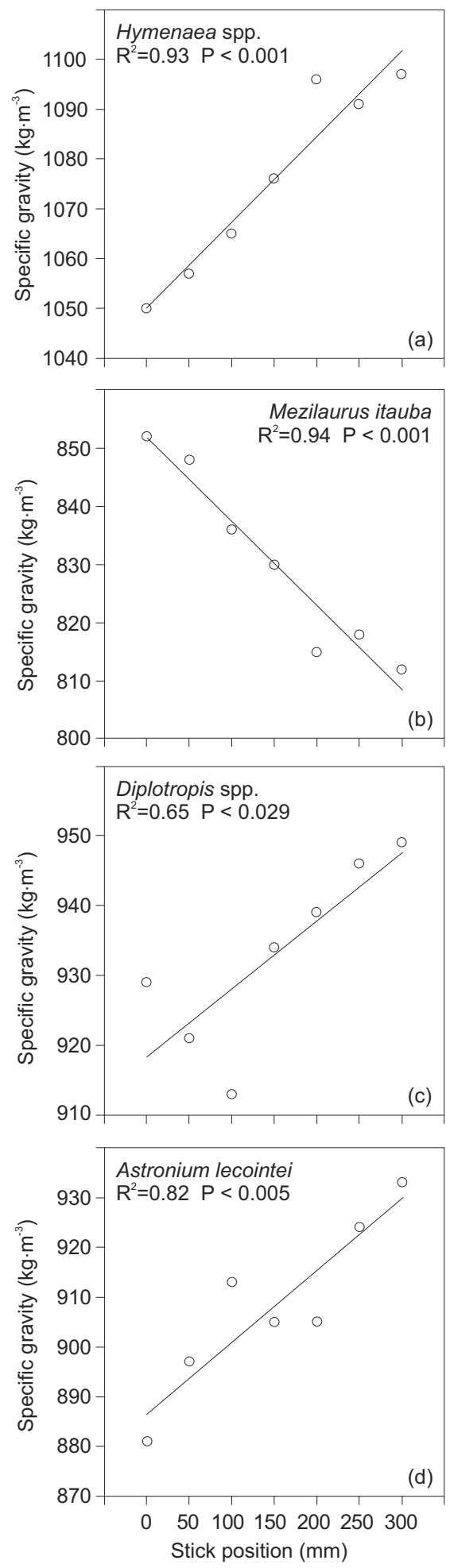

FIGURE 4 Relationships between specific gravity and short stick positions. Hymenaea spp. (a), Mezilaurus itauba (b), Diplotropis spp. (c) and Astronium lecointei (d).

FIGURA 4 Correlações entre densidade aparente e as posições nas varetas curtas. Hymenaea spp. (a); Mezilaurus itauba (b), Diplotropis spp. (c) e Astronium lecointei (d). 


\section{Physical and mechanical properties of the samples $(50 \mathrm{~mm})$}

Volumetric shrinkage in Diplotropis spp. was similar to that of $C$. echinata. The shear and compression tests showed similarities among A. lecointei, Handroanthus spp. wood and the control group (Figure 5).
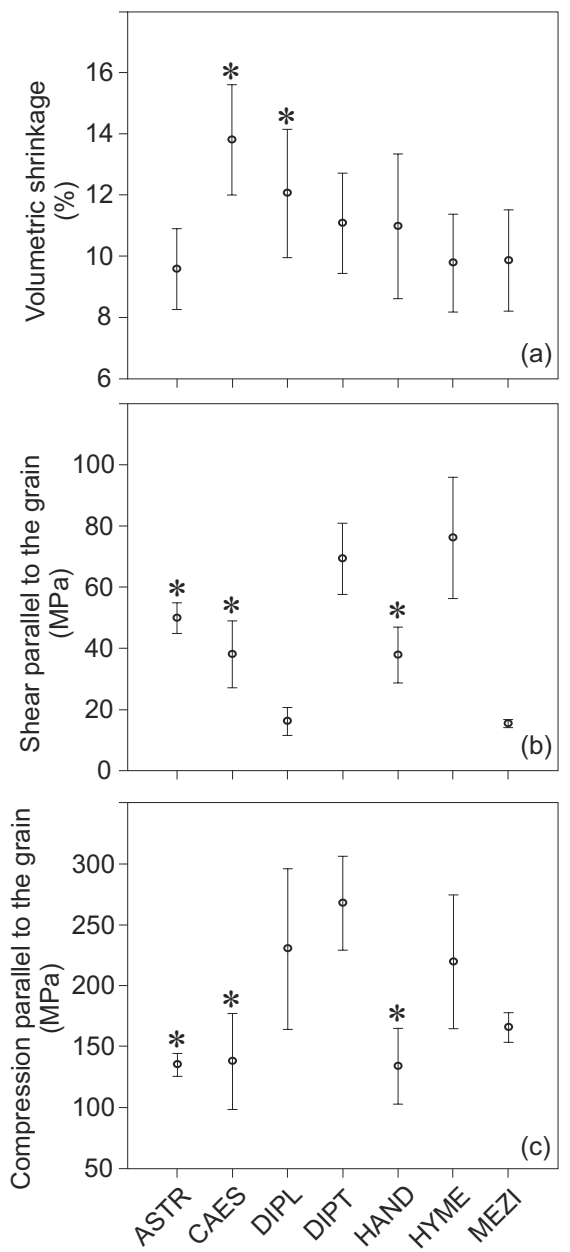

FIGURE 5 Variation in shear parallel to the grain (a) compression parallel to the grain (b) and volumetric shrinkage (c). Asterisks indicate that the woods are similar to $C$. echinata $(P<0.00 I)$ by Multiple Comparisons versus Control Group (Dunn's Method). Astronium lecointei (ASTR), Caesalpinia echinata (CAES), Diplotropis spp. (DIPL), Dipteryx spp. (DIPT), Handroanthus spp. (HAND), Hymenaea spp. (HYME), Mezilaurus itauba (MEZI).

FIGURA 5 Variação na resistência ao cisalhamento paralelo à grã $(\mathrm{a})$ compressão paralela à grã $(\mathrm{b})$ retração volumétrica $(\mathrm{c})$. Asteriscos indicam similaridades com C. echinata $(\mathrm{P}<0.00 \mathrm{I})$ pelo Multiple Comparisons versus Control Group (Dunn's Method). Astronium lecointei (ASTR), Caesalpinia echinata (CAES), Diplotropis spp. (DIPL), Dipteryx spp. (DIPT), Handroanthus spp. (HAND), Hymenaea spp. (HYME), Mezilaurus itauba (MEZI).

\section{DISCUSSION}

The wood of Handroanthus spp. and Diplotropis spp. showed the highest number of similarities when compared with $C$. echinata wood. However, in the manufacture of test bows, only Handroanthus spp. was promising. Therefore, in the selection of woods for bows, key properties that are similar to those of $C$. echinata are important determinants of quality.

Alves et al. (2008b), Matsunaga et al. (1996) and Wegst (2006) showed that density is one such property, and according to Longui et al. (20 I0a), wood density near I,000 $\mathrm{kg} \cdot \mathrm{m}^{-3}$ meets one of the requirements for quality bows. In the present study, despite the fact that the specific gravity of Diplotropis spp. and Hymenaea spp. did not statistically differ from $C$. echinata, variation in specific gravity along the sticks was evident. Specific gravity also varied in $A$. lecointei and M. itauba, but it did not vary in Handroanthus spp. and Dipteryx spp., indicating that these woods are more homogeneous compared to the others. Therefore, even though specific gravity is close to $I, 000 \mathrm{~kg} \cdot \mathrm{m}^{-3}$, these results suggest that density is not homogeneous along the stick, and, therefore, the stick would not meet the standard (LONGUl et al., 20।0b). In fact, bow manufacture would be difficult under these circumstances since heterogeneity would lead to sections of increased resistance to cutting instruments along the stick, thus making it more difficult to provide equilibrium to the bow. This fact will mean greater difficulty for the musician, who will have to compensate for the disequilibrium by changing the pressure on the bow during its handling.

Speed of sound propagation is another determinative property of bow quality (ALVES et al., 2008b; LONGUl et al., 20I0a). In the present study, Handroanthus spp. showed no difference in the speed of sound propagation as compared to $C$. echinata. However, the specific gravity of Handroanthus spp $(\approx$ $\left.870 \mathrm{~kg} \cdot \mathrm{m}^{-3}\right)$ was lower than the value considered optimal for quality bows $\left(1,000 \mathrm{~kg} \cdot \mathrm{m}^{-3}\right)$. Despite the low density, the thick-walled fibers of Handroanthus spp. and wood homogeneity may explain the favorable performance, enabling high sound propagation through the wood (BUCUR et al., 2002) and conferring quality to the bow.

Properties related to the stiffness of the wood also have a crucial role in the quality of the bow, and Dipteryx spp. (MOE ${ }_{d}$ and MOR), Hymenaea spp. (MOE $)$ and Diplotropis spp. (MOR) were, respectively, similar to $C$. echinata. Studying samples of $C$. echinata for violin bows, Schimleck et al. (2009) found a higher MOE for samples of high quality $(25,200 \mathrm{MPa})$, while samples of lower quality $(18,900 \mathrm{MPa})$ were close to samples of Dipteryx spp. (18,777 MPa) in the present study. 
Because the stick is subject to constant shock that can cause breakage, resistance to rupture is another important factor in the quality of the bow. In this study, a higher value of MOR was found in Hymenaea spp. (188 $\mathrm{MPa})$; however, this was below the value mentioned by Alves et al. (2008b) for high-quality sticks of $C$. echinata (196 MPa). The samples of $C$. echinata in this study showed values around $170 \mathrm{MPa}$ and differed from Dipteryx spp. and Diplotropis spp., suggesting that MOR $\approx 170 \mathrm{MPa}$ is suitable for bow sticks.

The study of volumetric shrinkage in wood for bows may indicate bow behavior over time. For example, if the frog, i.e. the bottom part of the bow nearest to the hand, presents some loosening, this will be reflected in the difficulty of tensioning the horsehair. Also, the wood might develop microcracks by the constant exchange of moisture with the environment, which may cause disruption when the bow works under tension. According to Franco and Yojo (2008), wood used in the bows should preferably have low values of volumetric shrinkage, which will ensure less variation in the sticks' dimensions when the bow is transported to environments with different humidity. According to Araújo (2007), the presence of water implies differences in density and, hence, the mechanical strength of wood. In most situations, it is not possible control the humidity, and as the wood is hygroscopic material, water content tends to be balanced with the environment. These changes cause variations in the physicomechanical properties, which may reflect the durability and playability of the bow. In this study, C. echinata and Diplotropis spp. showed the highest values of volumetric shrinkage $(\approx$ $14 \%)$, suggesting that this percentage is not a dominant criterion of bow quality.

In woods for bows, knowledge of the shear values can predict if the wood has sufficient strength to prevent the slipping of the cells when the bow is tensioned, especially at the head of the stick, which is exposed to great stress when bent. According to Franco and Yojo (2008) and Matsunaga and Minato (1998), higher shear strength is important in wood for bows because this feature can prevent breakage. In a study with $C$. echinata, Manilkara bidentata, Dialium sp. Swartzia fistuloides and Eucalyptus pilularis, Matsunaga and Minato (1998) reported that shear force is strongly related to density, even though $M$. bidentata had a greater shear value $(23.9 \mathrm{MPa})$ than $C$. echinata $(22.5$ $\mathrm{MPa}$ ). When the shear value was divided by the density, the samples of $C$. echinata showed the highest values in strength: weight ratio.
Although the stick of the bow does not receive a strong compressive force, this must be considered since any piece when bent will be subject to compression. These forces occur in the bow at the top of the stick, as opposed to horsehair; therefore, resistance to compression is active when the bow is being prepared and also every time it is tensioned to adjust the horsehair. Thus, repeated efforts can often lead to some internal damage and affect the balance and playability of the bow. In $C$. echinata was find values for compression parallel to the grain $\approx 140 \mathrm{MPa}$, a value that seems to be enough for bow quality. According to Hoadley (2000), in the compression parallel to the grain, the fibers are flattened longitudinally. As such, was suggesting that wood fibers with thick walls and a large proportion should have better resistance to compression. Alves et al. (2008b) reported C. echinata wood showed about $60 \%$ of fibers, while that of Handroanthus spp. in the present study showed little difference at $55 \%$ of fibers (LONGUI et al., 20l0b).

The term grain, according to Wiedenhoeft (2010) is used to indicate the orientation of cells of the axial system; however, the grain does not seem to have a decisive influence on the wood quality for bows, because C. echinata, recognized as the best wood for bow makers, has interlocked grain, while Handroanthus, also recognized quality has straight grain (LONGUI et al., 20I I).

Wegst et al. (2007) investigated the properties of thirteen alternative materials, among them, ten species of wood, a palm tree, a bamboo and a carbonfiber reinforced polymer, and compared the results with those reported for $C$. echinata. The authors state that these materials could provide bows comparable to those of $C$. echinata, but only by their mechanical properties. In this study similar result was obtained because Handroanthus spp. and Diplotropis spp. showed three key properties similar to $C$. echinata. However, in practice, Diplotropis spp. did not provide test bows of high quality, suggesting that the underperformance is related to its anatomical structure, with larger vessels and of parenchyma compared to Handroanthus spp., which is structurally more similar to $C$. echinata (LONGUI et al., 2010a). Anatomically suitable woods for bows must have the following features: vessel diameter $\approx 110 \mathrm{~mm}$; vessel element length $\approx 350 \mathrm{~mm}$; vessel frequency $\approx$ 13 cells $\cdot \mathrm{mm}^{-2}$; ray height $\approx 230 \mathrm{~mm}$; ray width $\approx 20$ $\mathrm{mm}$; ray frequency $\approx 10$ rays $\cdot \mathrm{mm}^{-1}$; fiber length $\approx 1160$ $\mathrm{mm}$; fiber diameter $\approx 18 \mathrm{~mm}$; fiber lumen diameter $\approx 5$ $\mathrm{mm}$; fiber wall thickness $\approx 6 \mathrm{~mm}$ (ALVES et al., 2008b; LONGUI et al., 2010a, 20l0b). 
Concerning chemical constituents and their influence on the wood quality for bows, Matsunaga et al. (1996, 1999), Minato et al. (1997) and Sakai et al. (1999) observed that the impregnation of wood extractives removed from $C$. echinata, reduced the loss tangent $(\tan \delta)$ in other woods. However, Longui et al. (20I2) studied the influence of extractives, lignin and holocellulose on seven wood species used for bows and concluded that wood quality of a bow stick cannot be explained solely by the content of extractives, lignin and holocellulose since they varied significantly among the two woods with highest potential (Handroanthus and Dipteryx) and reference wood for modern bows (C. echinata). The authors observed that extractives content negatively influenced the performance index (PI, calculated by $\mathrm{PI}=\sqrt{ } \mathrm{MOE} / \rho$, where $\mathrm{MOE}$ is modulus of elasticity and $\rho$ is density) of $C$. echinata (LONGUl et al., 20I2). Alves et al. (2008a) and Schimleck et al. (2009) found a negative trend between high extractives content and the quality grading of the sticks for bows.

\section{CONCLUSIONS}

Our hypothesis was partially confirmed because Handroanthus spp. and Diplotropis spp. have the greatest number of similarities with $C$. echinata. However, in actual bow manufacture, only Handroanthus spp. showed significant results. Therefore, it is suggested that similarities in the key properties of specific gravity, speed of sound propagation and MOE, as well as an understanding of wood anatomy, can help in selecting the wood best suited for the manufacture of high-quality bows similar to the reference $C$. echinata wood. In practice, Handroanthus spp. and Dipteryx spp. produced bows of quality similar to those of $C$. echinata and are anatomically more similar to each other than to the other four woods investigated, irrespective of their properties.

\section{REFERENCES}

ALVES, E. S.; ANGYALOSSY, V.; LONGUI, E. L.; LOMBARDI, D. R.; AMANO, E.; VARGAS, A. O arco: arte e ciência. In: RIBEIRO, R. C. L. F.; BARBEDO, C. J.; ALVES, E. S.; DOMINGOS, M.; BRAGA, M. R. (Org.). Pau-brasil, da semente à madeira conhecer para conservar. São Paulo: Instituto de Botânica, 2008a. p. I46-I57.

ALVES, E. S.; LONGUI, E. L.; AMANO, E. Pernambuco wood (Caesalpinia echinata) used in the manufacture of bows for string instruments. IAWA Journal, Leiden, v. 29, p. 323335, 2008b.
ARAÚJO, H. J. B. Relações funcionais entre propriedades físicas e mecânicas de madeiras tropicais brasileiras. Floresta, Curitiba, v. 37, p. 399-4I6, 2007.

ASSOCIAÇÃO BRASILEIRA DE NORMAS TÉCNICAS. Projeto de estruturas de madeira: projeto NBR 7190/1997. Rio de Janeiro, 1997. 107 p.

BAINES, A. Musical instruments through the ages. London: Pengkin Books, 1961.

BRÉMAUD, I.; CABROLIER, P.; MINATO, K.; GÉRARD, J.; THIBAUT, B. Vibrational properties of tropical woods with historical uses in musical instruments. In: ESWM CONFERENCE WOOD SCIENCE FOR THE PRESERVATION OF CULTURAL HERITAGE, 2008, Braga. Proceedings... Braga: ESWM, 2008. I CD-ROM.

BUCUR, V.; LANCELEUR, P.; ROGE, B. Acoustic properties of wood in tridimensional representation of slowness surfaces. Ultrasonics, London, v. 40, p. 537-54I, 2002.

BUENO, E. Pau-Brasil. São Paulo: Axis Mundi, 2002.

FRANCO, N.; YOJO, T. Propriedades físicas, mecânicas e acústicas da madeira de Pau-brasil. In: RIBEIRO, R. C. L. F; BARBEDO, C. J.; ALVES, E. S.; DOMINGOS, M.; BRAGA, M. R. (Org.). Pau-brasil, da semente à madeira conhecer para conservar. São Paulo: Instituto de Botânica, 2008. p. I46-I57.

HOADLEY, B. Understanding wood: a craftsman's guide to wood technology. $2^{\text {nd }}$ ed. Newtown: Taunton, 2000. 280 p.

HOLZ, D. Acoustically important properties of xylophone-bar materials: can tropical woods be replaced by European species? Acta Acustica, Stuttgart, v. 82, p. 878-884, 1996.

LONGUI, E. L.; BRÉMAUD, I.; SILVAJÚNIOR, F. G.; LOMBARDI, D. R.; ALVES, E. S. Relationship among extractives, lignin and holocellulose contents with performance index of seven wood species used for bows of string instruments. IAWA Journal, Leiden, v. 33, p. I4I-I49, 2012.

LONGUI, E. L.; LOMBARDI, D. R.; ALVES, E. S. Potential Brazilian wood species for bows of string Instruments. Holzforschung, Berlin, v. 64, p. 5I I-520, 2010 a.

LONGUI, E. L.; LOMBARDI, D. R.; ALVES, E. S. Six potential woods for bows of stringed instruments: organoleptic properties, machining and commercial availability. Revista do Instituto Florestal, São Paulo, v. 23, p. 203-2 I6, 201 I.

LONGUI, E. L.; YOJO, T.; LOMBARDI, D. R.; ALVES, E. S. The potential of ipê (Handroanthus spp.) and maçaranduba (Manilkara spp.) woods in the manufacture of bows for string instruments. IAWA Journal, Leiden, v. 3I, p. I49160, $2010 b$. 
LUCCHI, G. The use of empirical and scientific methods to measure the velocity of propagation of sound. Journal Violin Society, Maitland, v. 9, p. I07-123, 1986.

MATSUNAGA, M.; MINATO, K. Physical and mechanical properties required for violin bow materials II: comparison of the processing properties and durability between pernambuco and substitutable wood species. Journal of Wood Science, Tokyo, v. 44, p. I42-|46, 1998.

MATSUNAGA, M.; MINATO, K.; NAKATSUBO, F. Vibrational property changes of spruce wood by impregnation with water-soluble extractives of pernambuco (Guilandina echinata Spreng.). Journal of Wood Science, Tokyo, v. 45, p. 470-474, 1999.

MATSUNAGA, M.; SUGIYAMA, M.; MINATO, K.; NORIMOTO, M. Physical and mechanical properties required for violin bow materials. Holzforschung, Berlin, v. 50, p. $511-517,1996$.

MINATO, K.; SAKAI, K.; MATSUNAGA, M.; NAKATSUBO, $F$. The vibrational properties of wood impregnated with extractives of some species of Leguminosae. Mokuzai Gakkaishi, Tokyo, v. 43, p. I035-1037, 1997.

RYMER, R. Saving the music tree. Smithsonian, New York, v. 35 , p. 52-63, 2004.
SAKAI, K.; MATSUNAGA, M.; MINATO, K.; NAKATSUBO, F. Effects of impregnation of simple phenolic and natural polycyclic compounds on physical properties of wood. Journal of Wood Science, Tokyo, v. 45, p. 227-232, 1999.

SCHIMLECK, L. R.; ESPEY, C.; MORA, C. R.; EVANS, R.; TAYLOR, A.; MUNIZ, G. I. B. Characterization of the wood quality of pernambuco (Caesalpinia echinata Lam.) by measurements of density, extarctives contente, microfibril angle, stiffness, color, and NIR spectroscopy. Holzforschung, Berlin, v. 6, p. 457-463, 2009.

SLOOTEN, H. J. van der; SOUZA, M. R. Avaliação das espécies madeireiras da Amazônia selecionadas para a manufatura de instrumentos musicais. Manaus: INPA, 1993. I4I p.

SOUZA, M. R. Classificação de madeiras para instrumentos musicais. Brasília: IBDF, 1983.

WEGST, U. G. K. Wood for sound. American Journal of Botany, Saint Louis, v. 93, p. |439-|448, 2006.

WEGST, U. G. K.; OBERHOFF, S.; WELLER, M.; ASHBY, M. F. Materials for violin bows. International Journal of Materials Research, Stuttgart, v. 98, p. 1230-1237, 2007.

WIEDENHOEFT, A. C. Structure and function of wood. In: Wood handbook: general technical report FPLGTR-190. Madison: USDA, 2010. p. 3-1-3-18. 